\title{
Preference Study of Marginal Society in Palembang City who Live in Subsidized Houses and Flats on the Need for Space as A Place for Activity
}

\author{
R. Marpen ${ }^{1, *}$ Ibrahim Ibrahim $^{1}$ HWS. Putra ${ }^{1}$ Anuar Bin Ismail ${ }^{1}$ \\ Affendi Bin Bahaudin ${ }^{1}$ \\ ${ }^{1}$ Jurusan Teknik Sipil, Politeknik Negeri Sriwijaya, Palembang \\ *Corresponding author.Email: riomarpen@polsri.ac.id
}

\begin{abstract}
Palembang city is one of the metropolitan cities in Indonesia. The strongest character is seen when the growth of the residential environment is quite dense and the economic level of the community is quite low. This is the impact of high land and property prices in big cities such as Palembang. The phenomenon is that a new family with a limited economy chooses to build a house on a plot owned by their parents or chooses to develop an existing old house. This has an impact on the increasingly dense residential environment that is not directed with irregular buildings. In South Sumatra alone, about 9,987 housing units are needed to accommodate a total of 63,845 residents or often referred to as the housing backlog. This issue is very important to provide solutions to problems related to meet the needs of housing in urban areas. Some of the solutions provided by the government are by making flats (rusun) or subsidized houses. However, the increasing number of members in the family who demand greater space requirements must be considered for the possibility of residential development carried out by people living in subsidized houses and flats. Through this research, it is hoped that the ideal standard for the development of a residential module can be formulated that can accommodate the growing needs of family activities in the concept of a modular house. In this research, identification, analysis, and formulation were carried out in several stages: (1) identification of standard forms of housing provided by the government; subsidized housing and flats, (2) collecting data on community preferences for the need for residential space development as a forum for their activities; with a sample of subsidized houses, flats, and densely populated settlements. Based on the results of the study of preference aspects, it can be concluded that subsidized housing and flats have been channeled to marginalized communities in need in terms of people who have low economic conditions. This can be seen from the observation that most of the houses are inhabited by their owners based on data taken from several flats and subsidized houses. Most of the occupations of residents of flats and subsidized houses are self- employed and traders who earn mostly less than 5 million. Most of the milk houses and subsidized houses are still in standard condition and have an area of approximately $36 \mathrm{~m} 2$.
\end{abstract}

Keywords: module, occupancy, space, modular house.

\section{INTRODUCTION}

\section{$1.1 \quad$ Background}

Our planet will be home by 9.6 billion people in 2050. The addition of more than two billion people, will certainly cause problems if not anticipated from now. One of them is the problem of housing or residence. In Indonesia, the housing backlog reached 7.64 million housing units in early 2020 . The data is divided into
6.48 million housing units for low-income people (LIP) non- fixed income, 1.72 million housing units for LIP fixed income and 0.56 million housing units for nonLIP.

Palembang city is one of the metropolitan cities in Indonesia. Population growth and increase along with the level of residential development in urban areas, as a form of the need for settlements and urban space activities. The strongest character is seen when the 
growth of the residential environment is quite dense and the economic level of the community is quite low. This is the impact of high land and property prices in big cities such as Palembang. This is a separate problem in urban areas to control the uncontrolled growth of settlements. Economic problems are one of the reasons when the need for housing / shelter urges every family without being supported by sufficient income to buy a residence. As a result, new families with limited incomes prefer to build and occupy family/parent houses which are developed both vertically and horizontally while they still have the remaining land.

In South Sumatra, about 9,987 housing units are needed to accommodate a total of 63,845 residents or often referred to as the housing backlog. Some of the solutions provided by the government are by making flats (rusun) or subsidized houses at several points in the city of Palembang. However, the increasing number of members in the family who demand greater space requirements must be considered for the possibility of residential development carried out by people living in subsidized houses and flats. In addition, for dense settlements that are not provided by the government, the community is also faced with economic conditions that make it impossible to develop housing with ideal materials.

The form of subsidized flats and simple houses that are generally provided by developers and the government usually have a large enough space size to accommodate activities and furnishings in them. For example, a $36 \mathrm{~m} 2$ type room can contain a bed, wardrobe, study table, and activity room. However, along with the increasing needs and the possibility of increasing family members, the spaces in the residence can become a multifunctional space that accommodates several activities and furnishings in it. For this reason, the formulation of an effective space module in this residence can be the basis for future developments in providing housing/occupancy for people in need.

\subsection{Research Objectives}

The objective of this research are:

1. To formulate the ideal standard of space requirements for simple house buildings.

2. To be able to formulate a flexible space dimension module to be developed with functions in the residence.

3. Formulate the possible form of residential development, so that the form of the residential unit module can be formulated.

\subsection{Problem Statement}

The problems in this research are:

1. There is a need for a research of the ideal standard of residential housing, both based on people's preferences and habits in living activities.

2. There is a need for a research related to the ideal or effective and efficient space module in a residence.

3. It is necessary to analyze the direction of residential development that is usually carried out by the community; the type of space developed, as well as activities that require the development of a residence.

\subsection{Problem boundary and Study Scope}

The problem boundaries and study scope in this study include:

1. Within the scope of the area, the research was conducted by taking a sample of the object of research in the lower mid-class settlements in Palembang city (flats, subsidized housing, and solid settlements).

2. The scope of the research material is:

a. identification of standard forms of housing provided by the government; subsidized housing and flats,

b. collecting data on community preferences for the need for residential space development as a forum for their activities; with a sample of subsidized houses, flats, and densely populated settlements,

c. research of human standards and interior spaces in activities,

d. modelling activity space and development possibilities that can be done by existing residential modules

\section{RESEARCH METHOD}

\subsection{Research Stages}

The research was conducted by using a qualitative method, where the description and analysis were based on the deepening of the material in the field. The steps in this research begin by conducting a preliminary study which includes: introduction to the study area, literature review, survey, identification of data and software used. From the preliminary study carried out, continued with the identification of the problem so that the background of the problem and formulation of the problem and the determination of the objectives of this research can be drawn up. 
The research steps are shown in the following research flow chart:

\subsection{Literature study}

Several sources of literature that can be used include abstracts of research results, indexes, reviews, journal reference books.

1. The abstract of the research results is a valuable source of reference because the abstract contains the essence of the research

2. The index provides book titles arranged according to the main description of each book but does not provide an abstract.

3. Reviews contain writings that synthesize works or books that have been written in a certain period of time. The writings is arraged based on tipic and content.

4. Journals contain writings in the same disciplines, for example management science in economics or informatics engineering in computer science.

5. Reference books contain general writings in certain disciplines.

\subsection{Data Collecting}

\subsubsection{Type of data}

The data collection stage or survey implementation activities are intended to obtain complete data/information, including primary and secondary data.

1. Survey Implementation Phase, including:

a. Preperation: chek-list, kuesioner.

b. Administration process, license / introduction letter of survey

c. Site Survey

2. Method of Collecting Data, implemented through:

a. Survey Instansional, namely collecting primary and secondary data from relevant agencies, where the location of the study area is included in its administrative area. The data collection carried out includes:

b. Housing and settlement data (criteria: dense, slum, economy class)

c. Population data and economic conditions

d. Interviews, conducted with residents in the area where the survey was conducted. With the method of filling out the questionnaire carried out by the officer filling out the questionnaire.

e. Field Survey, in the form of direct observation in the field, especially regarding aspects of the physical condition of the location and aspects of community preferences

The types of data needed and the collection techniques are described in Table 3.1 below :

Table 1. The needs of research data

\begin{tabular}{|c|c|c|c|}
\hline No & Type of Data & $\begin{array}{l}\text { Method of } \\
\text { Collecting }\end{array}$ & $\begin{array}{c}\text { Source of } \\
\text { data / } \\
\text { Provide } \\
\text { Agencies }\end{array}$ \\
\hline 1 & $\begin{array}{l}\text { Data on the } \\
\text { distribution } \\
\text { area of } \\
\text { Marginal } \\
\text { settlements, } \\
\text { Flats and } \\
\text { Subsidized } \\
\text { Houses in } \\
\text { Palembang } \\
\text { City }\end{array}$ & $\begin{array}{l}\text { Secondary } \\
\text { Survey }\end{array}$ & $\begin{array}{l}\text { Dinas PU } \\
\text { and Perkim } \\
\text { / Bappe }\end{array}$ \\
\hline 2 & $\begin{array}{l}\text { Data of } \\
\text { Economic } \\
\text { level (social } \\
\text { economy of } \\
\text { the } \\
\text { community) }\end{array}$ & $\begin{array}{l}\text { Secondary } \\
\text { Survey }\end{array}$ & $\begin{array}{l}\text { Bappeda } \\
\text { BPS Kota } \\
\text { Palemban }\end{array}$ \\
\hline 3 & $\begin{array}{l}\text { Layout form } \\
\text { of simple } \\
\text { residential } \\
\text { space }\end{array}$ & Primary Survey & $\begin{array}{l}\text { Interview } \\
\text { with } \\
\text { community } \\
\text { respondents }\end{array}$ \\
\hline 4 & $\begin{array}{l}\text { Questionnaire } \\
\text { data related } \\
\text { to community } \\
\text { preferences } \\
\text { in residential } \\
\text { development }\end{array}$ & Primary Survey & $\begin{array}{l}\text { Interview } \\
\text { with } \\
\text { community } \\
\text { respondents }\end{array}$ \\
\hline
\end{tabular}

\subsubsection{Research Location}

This research was conducted in a residential area of Palembang City :

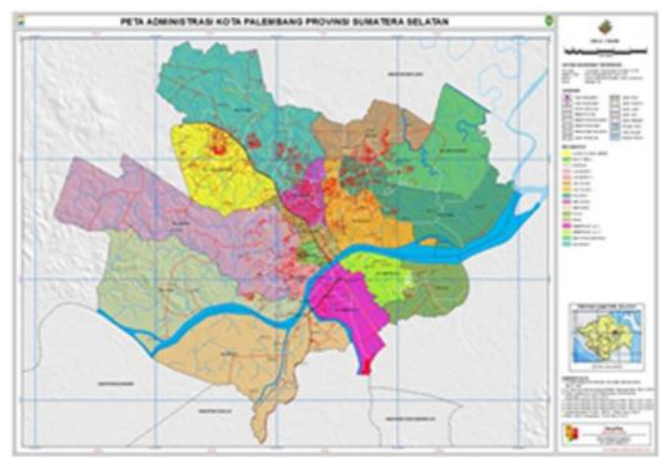

Figure 1 Research Location 


\subsection{Data analysis}

The analysis that used in this research is a comprehensive identification, categorization and interpretation of the layout and direction of residential development through several analytical techniques, namely:

1. Identification Method. This activity was carried out after all the information and data had been collected based on some of the focus of the research above. This identification is simply done based on the important points and things of interest as well as the similarity of information and the views of the informants.

2. Categorization Method, namely grouping data based on identification results juxtaposed in a matrix based on the focus of the research and sources of information. Categorization is also carried out as the basis for the preparation of a logical framework.

3. Interpretation method, which is carried out after linking the relationship between data. Interpretation is also carried out accompanied by relevant related theories. In accordance with the rules of qualitative research, through the selected analysis method, the research team can make interpretations and can have strong arguments based on data obtained from the field.

\subsection{Formulation of Conclusion}

The formulation of conclusions is carried out from the results of the analysis carried out previously. In the conclusion, the minimum residential space requirements are formulated, the ideal module for a simple residence that can be developed, as well as modeling the possible forms of development that can be carried out in the residence.

From the results of this formulation, then it is used as guidance in the development of advanced residential modules in the form of structural module / structural component analysis in supporting the sample of formation of a PolSri knockdown house.

\section{RESULTS AND DISCUSSION}

\subsection{Research Location Knowledge}

South Sumatra with Palembang as its capital is the second largest city in Sumatra after Medan. With a very large population growth causes the need for housing to increase. The need for housing to start life for a new family is very difficult to fulfill because of the many other needs and unsupportive income. For marginalized communities, the existence of subsidized houses and rusunawa/mi is a very good choice as a solution for family housing. Therefore, the marginalized people who live in Rusunawa/mi and subsidized houses in the Palembang area are the authors' choice as the study area in this research.

\subsection{Building Owner Preference}

Based on the results of the survey, it was found that $64.6 \%$ were self-owned while 35.4 were rented. (Chart 1)



Figure 2 Building Owner Preference

\subsection{Building Type Preference}

In the implementation of the survey, $49.8 \%$ of subsidized houses were carried out and $50.2 \%$ of flats. (figure 3)


Rumah Subsid Ruman Susun

Figure 3. Implementation of Survey

\subsection{Job Owner Preference}

The survey results show that the majority of building owners work as entrepreneurs by $33.5 \%$ and traders by $23 \%$. while those who work as Government Employees are 7.5\%. (Figure 4).

Pekerjaan

239 responses
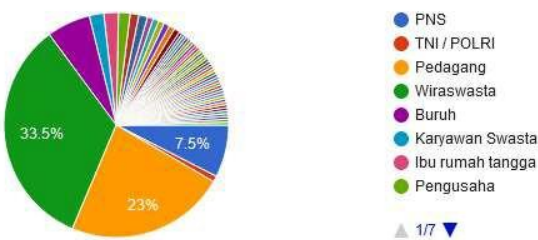

Figure 4 Job Owner Preference

\subsection{Marginal Society Income Preference}

The survey results show that most of the building owners have an income of 2 million to 5 million by $51 \%$ and less than 2 million by $23 \%$. while those with income of 5 million to 10 million are $8.8 \%$. for those who have an income of more than 10 million, there are still only a few. (Figure 5). 
Jumlah Penghasilan dalam 1 Bulan?

239 responses

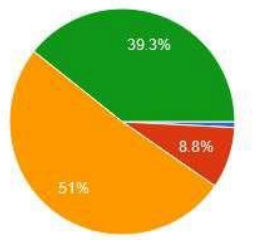

- $>10$ Juta

5-10 Juta

2-5 Juta

Figure 5 Marginal Society Income Preference

\section{6. $\quad$ Standard Building Preference}

Based on the survey results show that most of the buildings are still in standard condition at $79.9 \%$ and $20.1 \%$ have been developed. (Figure 6).

Apakah rumah / hunian yang Bapak/lbu tempati masih dalam kondisi standar atau tanpa pengembangan?

239 responses

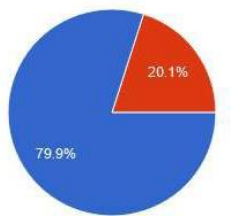

\section{Ya}

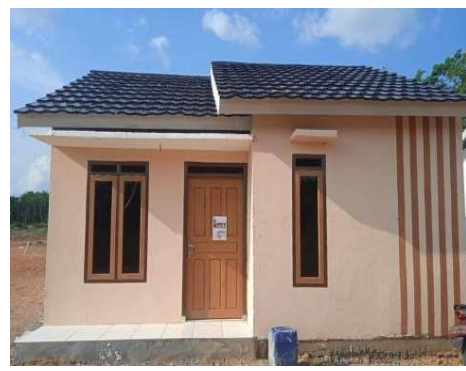

Figure 8 subsidized houses

\section{CONCLUSION}

Based on the results of the study of preference aspects, it can be concluded that subsidized housing and flats have been channeled to marginalized communities in need in terms of people who have low economic conditions. This can be seen from the observation that most of the houses are inhabited by their owners based on data taken from several flats and subsidized houses.

Most of the occupations of residents of flats and subsidized houses are self-employed and traders who earn mostly less than 5 million. Most of the milk houses and subsidized houses are still in standard condition and have an area of approximately $36 \mathrm{~m} 2$.
Some of the results of field observations regarding the condition of the buildings where the marginalized people live can be seen in the following figure. 


\section{REFERENCES}

[1] Badan Standarisasi Nasional . (1990). Spesifikasi Matra Ruang dan Rumah Tinggal. Jakarta: Badan Standarisasi Nasional .

[2] Badan Standarisasi Nasional. (2004). Tata cara Perencanaan Lingkungan Perumahan di Perkotaan. Jakarta: Badan Standarisasi National.

[3] Departemen Permukiman dan Prasarana Wilayah. (2002). Lampiran I Pedoman Umum Rumah Sederhana Sehat . In D. P. Wilayah, Pedoman Teknik Pembangunan Rumah Sederhana Sehat 9Rs Sehat). Jakarta: Kementerian Permukiman dan Prasarana Wilayah Republik Indonesia.

[4] Dwwi, N. K., \& Swanendri, N. M. (2007). Rancangan Rumah Tumbuh Tipe KPR BTN Di Kota Denpasar. PESAT, c21-c30.

[5] Poetra, B. L. (2016). Perancangan Perabot Multifungsi Untuk Ruang Huni Terbatas. INTRA, 790-797.

[6] Pusat Penelitian dan Pengembangan Permukiman . (2021). Rumah Ber-SNI: Membangun Rumah
Sejahtera. Kabupaten Bandung: Kementerian Pekerjaan Umum .

[7] Rully. (2014). Merencanakan dan Merancang Rumah Tinggal yang Optimal . Teknik Sipil dan Arsitektur, VOL. 15 NO. 19.

[8] Sholahuddin, M. (2017). Desain Interior Melalui Pendekatan Kebutuhan Pemakai Pada Hunian Terbatas. Lintas Ruang, 21-30. 2

[9] Suerni, T. (2013). Desain Interior Rumah Tinggal Minimalis: untuk Sekolah Menengah Kejuruan. Jakarta: Kemendikbud.

[10] Surowiyono, T. T. (2003). Dasar Perencanaan Rumah Tinggal . Jakarta: Pustaka Sinar Harapan.

[11] Suryo, M. S. (2017). Analisa Kebutuhan Luas Minimal Pada Rumah Sederhana Tapak di Indonesia. Jurnal Permukiman, 116-123.

[12] Widodo, L., Sukania, I. W., \& Sugiono, R. (2016). Rancangan Furniture dan Tata Ruang Dengan Dimensi Terbatas Secara Ergonomis. Teknik $\begin{array}{llll}\text { Industri, } & \text { Vol } & 4, & \text { No }\end{array}$ 